\title{
筑波研究学園都市における区画整理民有地の市街化に関する考察 STUDY ON URBANIZING PROCESS OF PRIVATELY OWNED LAND IN READJUSTED AREA OF TSUKUBA NEW TOWN
}

\author{
土肥博至*, 坂 本 淳二**, 田中一成***, 福本 佳 世**** \\ Hiroshi DOHI, Junji SAKAMOTO, Kazunari TANAKA \\ and Kayo FUKUMOTO
}

\begin{abstract}
The purposes here are to conclude our researches about urbanizing process of privately owned land in readjusted area of Tsukuba New Town for these 22 years, and to consider the contributing factors of this trend.

The movement of the urbanization there has been quite stable. They may be divided into three stages:

1) The first is stable urbanizing process before EXPO ' 85 ; 2) The second is rapid urbanization in the period of EXPO ' 85 and stagnation after that; 3 ) The third is ascending period with the actualization of urban potential after 1990.

The growth and the completion of the city center was the main factor of these trends. EXPO ' 85 contributed to the maturity of the city center, and facilitated the urbanizing process later on.
\end{abstract}

Keywords: Tsukuba New Town, Readjusted Area, Privately Owned Land, Urbanizing Process, Chronological Study 筑波研究学園都市, 区画整理, 民有地, 市街化, 時系列研究

\section{1. 研究の目的と方法}

筑波研究学園都市においての計画的造成が行なわれた区域約 2,700ha（研究学園地区）のうち土地区画整理事業施行区域の面積は 約1,100haである。その中で民有地注1)の総面積は，約 511haを占める (図 1参照)。民有地は，他の部分が全て公的事業者によって建設や 管理が行なわれている，いわば計画的建設用地であるのに対して， 極めて多数の一般地主や民間業者によって所有されている，いわば 非計画的建設用地である注2)。前者の大部分が既にほぼ建設を終了 しているのに対して，後者は現在未だその多くが未建設であり，今 後なお相当長い期間の中で徐々に建設が進行すると考えられる部分 である。

従って，この都市の民有地に㧈ける建設の動向，土地利用や権利 関係の変化等, 市街化の経時的な変化とその要因を把握することは, 計画都市の形成過程を理解し, 今後の新都市開発を考える上で重要 な手がかりとなるものである。

こうした視点から筆者らは，民有地のビルトアップ注3)が開始さ れた直後の1977年6月（この時に1973年についても遡って調査した） から，ほほ $2 \sim 3$ 年間隔で民有地全体を対象とした定点的市街化実 態調査を行ない，その都度結果を報告してきた注4)。

本研究は，22年にわたる調査結果を基に，民有地の市街化動向を
総括するとともに，筑波研究学園都市の都市形成動向及び都市をと りまく周辺地域の状況との関係から，民有地の市街化の要因につい て考察するものである。

区画整理民有地の市街化を扱った研究としては，区画整理事業に よる市街地形成の計画的課題を記述した文11，ロジスティックモデ ルによる市街化曲線を検討した文12，事業計画を基準に事業の経過 特性を検討した文13，市街化過程に数理モデルを適用しながらその 構造特性を検討した文14などがあるが，いずれも分析デー夕は1な いし数時点のものであり，民有地ビルトアップの傾向の把握を中心 とした研究であり，市街化の要因までは触れていない。本研究は， 定点的時系列研究としては，その継続性において他に類を見ないも のであり，また民有地の市街化要因を検討することに特色をもつも のである。

次に調査の方法について述べる。調査は表 1 に示す11時点につい て行った。ビルトアップは，基本的に現地の観測を主とし，建築形 態・用途·集合住宅における戸数・敷地形状を現地で記録し，敷地 境界, 専用建築 - 併用建築の区別なと不明な点については，適宜居 住者にヒアリングを行い確認した。敷地面積は，現地記録を2,500分 の1換地図（換地の単位となった筆界が記入されている）に整理し た上で，地籍図及び文15を基礎資料として算定した注5)。
* 神巨芸術工科大学 教授・工博

** 筑波大学環境科学研究科 準研究員 - 学修

*** 株式会社宅地開発研究所 研究員・博士 (デザイン学)

**** 筑波大学大学院博士課程芸術学研究科 大学院生・修士 (デザイン学)
Prof., Dept. of Environmental Design, Kobe Design Univ., Dr. Eng.

Research Assoc., Inst., of Environmental Sciences, Univ. of Tsukuba, M: E. Sciences Researcher, Takken City Planning Consultants Inc., Ph. D.

Graduate Student, Doctoral Program on the Science of Art and Design; Univ. of Tsukuba, M. Design 
また，民有地の市街化の地域的特性を把握するために，研究学園 都市の北から南に, 北部, 都心北, 都心，都心南，南部の 5 つのゾ ーンに区分し，それぞれの市街化動向を観察することとした。

さらに，市街化の構造を検討するために，民有地の建物を住居専 用か非居住施設垪用力専用非居住施設か，及ひ独立型か集合型かと いう $2 つ の$ 観点から 6 分頑した。

\section{2。民有地の市街化動向}

まず民有地の市街化動向を概観する。表 1 は，11の調査時点にお ける民有地全体の市街化状況をまとめたものである。また，図2は， 民有地全体及び5ゾーンの市街化面積率（民有地の総建筑㪟地面積 を民有地面積で除した值）の推移を示したものである。1995年5月 現在の総建物数は，5,720榑，25,373戸，2,137店舗であり，総建物敷 地面積は 2662 haで民有地総面積（511.2ha）の 521\%であり，22年間 に押ける市街化面積率の増加度（以下市街化速度と呼ぶ）は年平均 で275\%であった。

時系列にみると，1梖あたりの戸数（建物規模）は一貫して増加 しているが，全体に占める非居住施設の割合（表 1 の店舗化率）は， 1982年を頂点として, 以降ほほ一貫して減少している。これは民有 地の市街化過程初期に扔いて店舗やサービス施設の建築が先行する

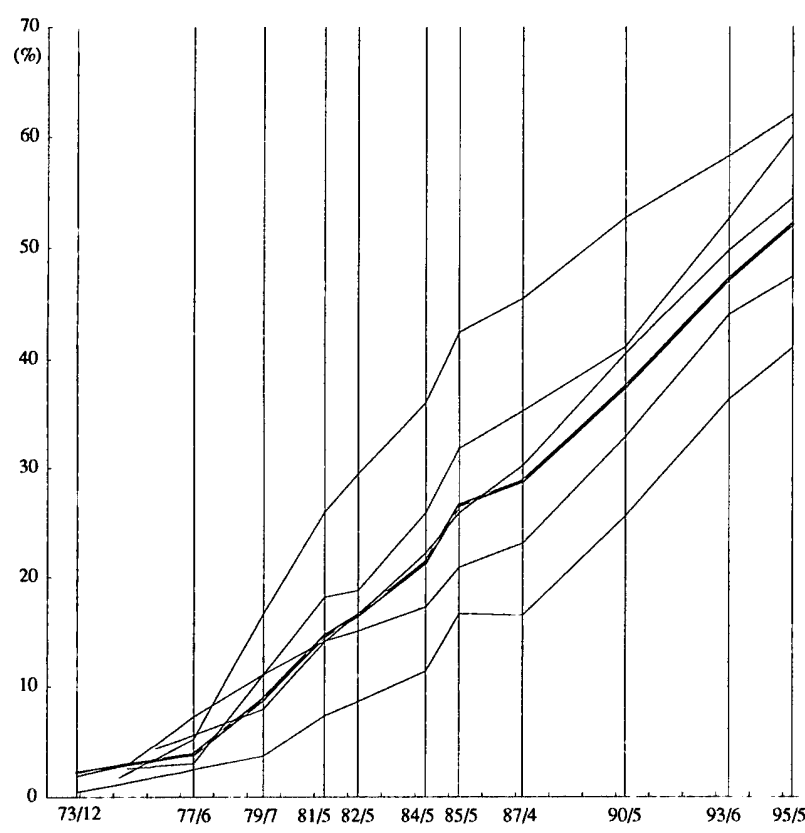

図2。市街化面倩浚の推䮈

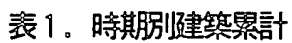

\begin{tabular}{|c|c|c|c|c|c|c|c|c|c|c|c|c|c|}
\hline & 計 画 & 1973.6 & 1977.8 & 1979.7 & 1981.5 & 1982.5 & 1984.5 & 1985.5 & 1987.4 & 1990.5 & 1993.6 & 1995.5 & 備 \\
\hline \multirow[t]{2}{*}{ 棈 数 } & 11,090 & 130 & 300 & 861 & 1,591 & 1,869 & 2,489 & 2,955 & 3,396 & 4,372 & 5,286 & 5,720 & (楎) \\
\hline & $100.00 \%$ & 1.2 & 2.7 & 7.8 & 14.3 & 16.9 & 22.4 & 26.6 & 30.6 & 39.4 & 47.7 & 51.6 & (\%) \\
\hline \multirow[t]{2}{*}{ 住戸数 } & 11,090 & 122 & 1,048 & 2,822 & 5,285 & 6,072 & 9,223 & 11,804 & 13,579 & 18,289 & 22,711 & 25,373 & (戸) \\
\hline & $100.00 \%$ & 1.1 & 9.4 & 23.6 & 47.7 & 54.8 & 83.2 & 106.4 & 122.4 & 164.9 & 204.8 & 228.8 & $(\%)$ \\
\hline 店舗数 & $=$ & 10 & 70 & 367 & 721 & 861 & 1,042 & 1,270 & 1,353 & 1,669 & 1,988 & 2,137 & (店舗) \\
\hline 戸数率 & & 1.2 & 10.1 & 26.9 & 54.2 & 62.5 & 92.6 & 117.9 & 137.7 & 180 & 222.8 & 248.1 & 住戸・店舗数／計画戸数 \\
\hline 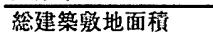 & $5,112,453$ & 110.807 & 198,287 & 453,342 & 748.853 & 844,295 & $1,094,765$ & $1,343,983$ & $1,474,461$ & $1,918,918$ & $2,414,072$ & $2,661,848$ & $\left(\mathrm{~m}^{2}\right)$ \\
\hline 市街化面积率 & $100.00 \%$ & 2.2 & 3.9 & 8.9 & 14.8 & 16.5 & 21.4 & 26.3 & 28.8 & 37.5 & 47.2 & 52.1 & (\%) \\
\hline 市街化速度(年平均) & & $=$ & 1.70 & 2.40 & 3.11 & 1.90 & 2.45 & 5.20 & 1.15 & 2.82 & 3.15 & 2.56 & 1973～1995年平均 $2.75 \%$ \\
\hline 建物規模 & & 1 & 3.7 & 3.5 & 3.8 & 3.7 & 4.1 & 4.4 & 4.4 & 4.6 & 4.7 & 4.8 & 可/榑 \\
\hline 㰲地規模 & 460 & 851 & 661 & 527 & 470 & 452 & 440 & 455 & 434 & 439 & 457 & 465 & 敷地面積／榑 \\
\hline 歇地规模 & 460 & 838 & 177) & 152 & 125 & 122 & 107 & 103 & 99 & 96 & 98 & 97 . & 敷地面積/戸・店舗 \\
\hline 店舗比 & & 8.2 & 6.7 & 14 & 13.6 & 14.2 & 11.3 & 10.8 & 10 & 9.1 & 8.8 & 8.4 & 店舖数／住戸数（\%) \\
\hline
\end{tabular}

傾向を示すものであり，これは公的市街地が先行的に整㣁され，そ の住宅地居住者や研究所・事業所関係者に対する需要に対応するも

市街化面積率と市街化速度に着目すると，1973年からゆるやかに 上昇を始めた市街化曲線は，1977年以降安定した上昇傾向にあった ことが分かる。その後1984年から1985年にかけて市街化速度が年平 均5.21\%と突出するがこれは主に筑波科学万博（1985年 3 月～9 月

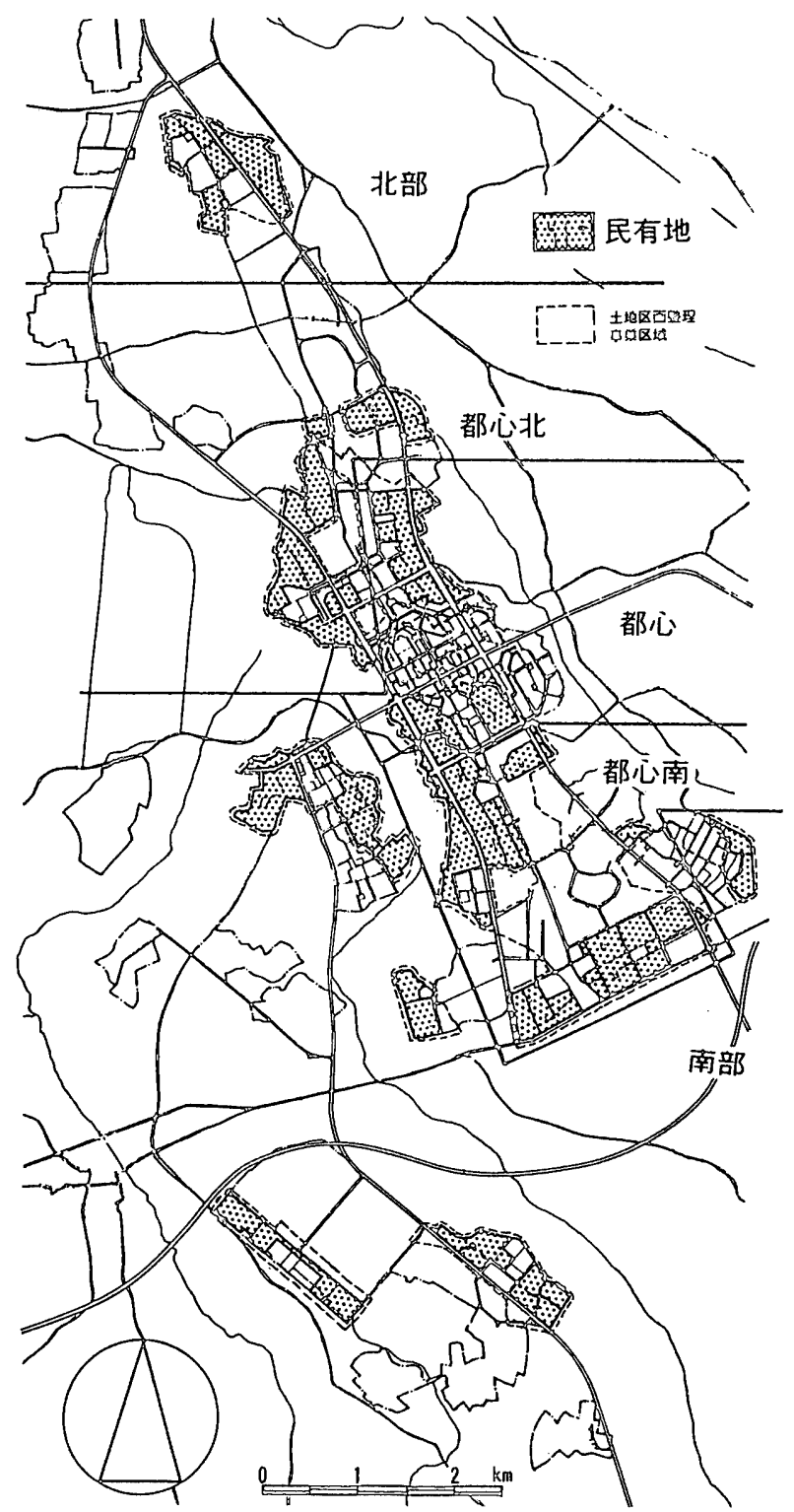

圆1。民有地位置圆 ので，職住一体型のこの都市の特徽的な現象といえる。 
開催）の影響であり，その後1987年までやや上昇が鈍化したことは (市街化速度 $1.33 \%$ ), 万博開催による一時的な市街化の急激な進行 の後のゆれ杘しを示しており，1987年から1990年にかけて，再び安 定した市街化ぺースに戻ったといえる。

その後1990年から1993年の間では, 万博直前の 1 年間を別とする と, 年平均 $3.1 \%$ と過去最大の伸び率となった。全国的には, バブ ル崩壊による建築活動の停滞時期であったが, 研究学園都市の民有 地では活発な建築活動が生じていたことになる。しかし1993年から 1995年の2年間では，年平均で2.6\%と前者に比較して市街化は減速 した。これは全国的な建築活動の停滞傾向がようやく伝播してきた こと，新都市において既に一部地区で市街化面積率が $60 \%$ を超え， 建て詰まりの状況が生じてきたことなどによると考えられる注の。

ゾーンに注目すると，使用収益開始後の数年間を除くと，市街化 面積率は, 都心, 都心北, 都心南, 北部, 南部の順に並んでおり, 都心部を中心にビルトアップが進む都市の同心円的構造を見ること ができる。1987年には, ゾーン間のビルトアップの格差は最大とな った。しかし1990年以降ゾーン間の格差は縮小する傾向にある。都 心では，ビルトアップが最も活発であり，1985年以降その速度は鈍 化しており，都心部の建て詰まりの様子がうかがえる。一方都心に 近い都心北，都心南では，1990年以降ビルトアップが活発化してい る。この傾向は北部，南部においても観察できるものである。すな わち, 民有地の市街化状況は, 万博開催の1985年を境にして, それ 以前の計画的建設期と万博以降の展開期とで大きく異なることが分 かる。

1979年以降の民有地全体及び各ゾーンの建築種別構成の推移を表 2 に示した。全体の傾向として棟数比では独立専用住宅が，3割程 度と最も多いが，時間の経過に伴い漸减する傾向にある。一方集合 専用住宅は, 棟数比, 敷地面積比とも増加する傾向にあり, 敷地面 積比については1990年に, 33.8\%と独立専用住宅(35.4\%)に代わって 最も大きくなり，以降その差は大きくなっている。

ゾーン別に見ると, 北部, 都心北では, 集合専用・集合併用住宅 からなる集合型住宅の割合が80\%を超えている。特に都心北では,

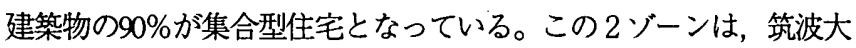
学など大学が近接するゾーンのため, 学生向けのアパート・マンシ ヨンの建築が卓越しており, 研究学園都市民有地の特色をリードし ていることが分かる。

一方, 都心南, 南部は独立専用住宅及ひ独立併用住宅からなる独 立型住宅が20〜30\%と, その他のゾーンに対し相対的に高く, 戸建 住宅地としての性格も有しているが，その割合は時間の経過に伴い 低くなっており，集合型住宅の構成比が高くなっている。

\section{3. 民有地の市街化動向と関連諸指標の関係}

研究学園都市の民有地の市街化の要因については, これまでの報 告において, 大学の活動の影響, 周辺農村の都市化, 民間研究所な どの研究開発機能の立地など時期毎に触れてきた注7)。ここでは, これまでの研究学園都市の形成と都市的成長を踏まえて, 市街化の 要因について考察を行う。市街化の動向を示す指標として市街化面 積率を用い, これとと研究学園都市の形成状況を示す指標群及び都 市と東京, 茨城県南, 周辺農村との関係を示す指標群との, 時系列 的な関係を総観する。
関連指標としては，以下の 8 指標を用いる。 (1)公的市街地市街化面積率：研究学園都市の計画部分の形 成状況

(2)都心地区建築床総面積: 都心の形成状况

(3)研究所数 : 学園都市の特色である研究開発機能の状況

(4)集合住戸率：民有地内の集合型住宅戸数の状况

(5)東京とのアクセス：常磐線，高速バスなと東京に向かう

公共交通手段数で, 東京都心へのアクセスの多様性·利 便性を示す。

(6)昼夜間人口比：学園都市の位置する茨城県南地域におけ

る従業地としての相対的位置を示す。

(7)小売販売額比(対土浦)：従来の地域中心都市である土浦市 との影響関係

(8)専業農家率(つくば巾)：周辺農村地域の変容状況

図 3 は，1973年から1995年までの上記各指標の年次推移を示した ものである。これを見ると指標間には，類似する変化パターンを観 察できる。

まず立ち上がりにおいて急激な上昇を見せるが，1980年の概成を 経てゆるやかな増加に転じるするパターンがある。これは公的市街 地市街化面積率と集合住戸率が該当する。また減少傾向であるが, 専業農家率も同様のパターンをとるものと見なしうる。公的市街地 では，概成時までに大半がビルトアップされ，それに伴い，特に大 学活動の影響を受けて集合住戸率が急激に上昇したものと考えられ る。一方専業農家率は, 全国的な兼業化動向もあるが, 学生向けア パートの建設が, 農家の所有する土地を中心としたものであったこ とも無関係ではないと思われる。

これに対して一定した直線的な上昇を示すパターンが見られる。 市街化面積率, 小売販売額比 (対土浦), 昼夜間人口比及び東京へ のアクセスがこれに該当する。ただし前 2 者は後 2 者に比較して上

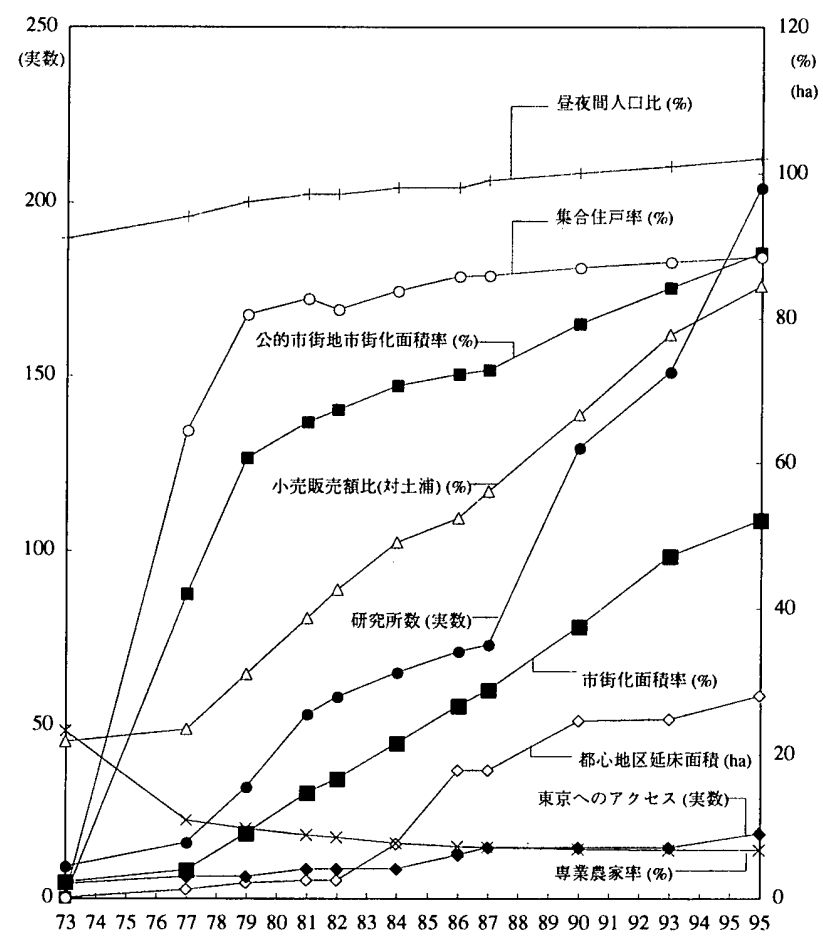

図3.各指標の推移 
䘚 2。建築種別舫成比(1979.7 1995.5)

\begin{tabular}{|c|c|c|c|c|c|c|c|c|c|c|c|c|c|c|c|c|c|c|c|c|c|c|}
\hline \multirow[t]{2}{*}{ r-» } & \multirow[t]{2}{*}{ 調㾕年月 } & \multicolumn{2}{|c|}{ 独立尃用住宅 } & \multicolumn{3}{|c|}{ 集合尃用住宅 } & \multicolumn{3}{|c|}{ 独立併用住宅 } & & 集合 & 併用住 & & 非居住 & 扸設独立型 & 非居 & 话住施設 & 集合型 & & & 話 & \\
\hline & & 槙敛 & 殃地面和 & 楼致 & 巨致 & 敌地面和 & 棈敦 & 店铇政 & 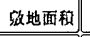 & 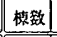 & 戸致 & 店醏致 & 敃地面积 & 铱敦 & 练地面程 & 校致 & 店的㣀 & 珹地面积 & 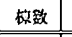 & 户敖 & 䜿钴致 & 这地面数 \\
\hline & 1979.7 & 429 & 0.29 & 168 & .976 & 92.03 & 83 & 83 & 39.69 & 17 & 134 & 26 & 12.68 & 141 & 83.39 & 23 & 117 & 15.27 & 861 & 2,622 & 367 & 453.34 \\
\hline & & 8 & 46.4. & 19.5 & - & 20.3 & 9.6] & - & 8.8 & 2.0 & - & - & 2.8 & 16.4 & 18.4 & 2.7 & - & 3.4 & - & - & - & - \\
\hline 民 & 1981.5 & 787 & 315.97 & 366 & 4,072 & 181.00 & 135 & 141 & 58.29 & 30 & 291 & 67 & 21.28 & 217 & 136.73 & 56 & 296 & 35.38 . & 1.591 & 5,285 & 721 & 748.65 \\
\hline 有 & & .5 & 42.2 & 23.0 & - & 24.2 & 8.5 & - & 7.8 & 1.9 & - & - & 2.8 & 13.6 & 18.3 & 3.5 & - & 4.7 & - & $=$ & $=$ & - \\
\hline 地 & 1982.5 & 989 & 352.27 & 407 & 4,598 & 195.85 & 160 & 171 & 73.25 & 35 & 325 & 103 & 23.54 & 212 & 152.52 & 66 & 375 & 46.87 & $|1,869|$ & 6,072 & 861 & 844.30 \\
\hline 全 & & 52.9 & 41.7 & 21.8 & - & 23.2 & 8.6 & - & 8.7 & 1.9 & - & - & 2.8 & 11.3 & 18.1 & 3.5 & - & 5.6 & - & - & - & - \\
\hline 体 & 1984.5 & 1,313 & 449.43 & 586 & 7,172 & 284.05 & 196 & 211 & 90.02 & 51 & 542 & 139 & 32.39 & 262 & 185.62 & 81 & 430 & 53.26 & $|2,489|$ & 9,223 & 1,042 & $1,094.77$ \\
\hline- & & 52.8 & 41.1 & 23.5 & $=$ & 25.9 & 7.9] & - & 8.2 & 2.0 & - & - & 3.0 & 10.5 & 17.0 & 3.3 & - & 4.9 & - & - & $=$ & - \\
\hline $\mathrm{T}$ & 1985.5 & 1,470 & 498.59 & 769 & 9,285 & 385.66 & 214 & 229 & 96.83 & 78 & 835 & 192 & 48.96 & 322 & 246.76 & 102 & 528 & 67.19 & 2,955 & $\mid 11,804$ & 1,271 & $1,343.9$ \\
\hline 段 & & 49.7 & 37.1 & 26.0 & - & 28.7 & 7.2 & - & 7.2 & 2.6 & - & - & 3.6 & 10.9 & 18.4 & 3.5 & - & 5.0 & - & - & $=$ & - \\
\hline は & 1987.4 & 1,737 & 572.47 & 922 & 11,009 & 456.84 & 227 & 242 & 103.48 & 84 & 920 & 210 & 54.36 & 360 & 271.66 & 111 & 565 & 72.51 & 3,441 & \begin{tabular}{|l|}
13,893 \\
\end{tabular} & $\begin{array}{l}1.377 \\
\end{array}$ & $1,531.32$ \\
\hline 推 & & 50.5 & 37.4 & 26.8 & - & 29.8 & 6.6 & - & 6.8 & 2.4 & - & - & 3.6 & 10.5 & 17.7 & 3.2 & - & 4.7. & - & - & - & - \\
\hline 成 & 1990.5 & 2,150 & 691.03 & 1,313 & 14,675 & 659.51 & $267 \mid$ & 288 & 120.28 & 123 & 1,360 & 301 & 77.90 & 435 & 315.58 & 139 & 684 & 87.91 & 4,427 & \begin{tabular}{|l|}
18,452 \\
\end{tabular} & \begin{tabular}{|l|l} 
& 1.708
\end{tabular} & $1,952.20$ \\
\hline 比 & & 48.6 & 35.4 & 29.7 & - & 33.8 & 6.0 & - & 6.2 & 2.8 & $=$ & - & 4.0 & 9.8 & 16.2 & 3.1 & - & 4.5 & - & $=$ & $=$ & - \\
\hline (\%) & 1993.6 & 2,475 & 767.96 & 1,636 & 18,081 & 891.72 & 279 & 279 & 126.07 & 155 & 1,861 & 360 & 107.76 & 570 & 414.81 & 171 & 785 & 105.75 & 5.286 & 22,696 & 1.994 & $2,414.07$ \\
\hline & & 46.8 & 31.8 & 30.9 & - & 36.9 & 5.3 & $=$ & 5.2. & 2.9 & - & - & 4.5 & 10.8 & 17.2 & 3.2 & - & 4.4 & - & - & $=$ & - \\
\hline & 1995.5 & 2,637 & 820.95 & 1,833 & 20,159 & $1,021.42$ & 307 & 319 & 141.82 & 178 & 2,270 & 402 & 129.00 & 564 & 432.10 & 202 & 853 & 117.76 & 5,721 & \begin{tabular}{|l|l|}
25,373 \\
\end{tabular} & 2,138 & $2,663.04$ \\
\hline & & 46.1 & 30.8 & 32.0 & - & 38.4 & $5.4 \mid$ & - & 5.3 & $\mid$\begin{tabular}{|l}
$\mid$ \\
$\mid$
\end{tabular} .1 & - & - & 4.8] & 9.9 & 16.2 & 3.5 & - & 4.4. & - & - & - & - \\
\hline & 879.7 & 46 & 24.83 & 25 & 323 & 14.75 & 9 & 9 & 3.69 & 2 & 15 & & 1.60 & 18 & 8.54 & 0 & t & 0.00 & 100 & 393 & 29 & 53.40 \\
\hline & 1981.5 & 69 & 32.41 & 39 & 429 & 19.08 & 12 & 12 & 4.83 & 3 & 20 & 3 & 1.91 & 22. & 9.49 & & & 0.30 & 14 & 530 & 39 & 68.0 \\
\hline 北 & 1982.5 & 79 & 24.53 & 48 & 523 & 22.02 & 18 & 18 & 11.14 & 4 & 23 & & 1.45 & 20. & 11.30 & & 16 & 2.02 & 174 & 643 & 6 & 72.45 \\
\hline & 1984.5 & 98 & 29.18 & 52 & 582 & 23.90 & 21: & 21 & 12.61 & d & 23 & & 1.45 & 24 & 13.99 & & 16 & 2.02 & 204 & 724 & & 83.14 \\
\hline & 1985. & 111 & 34.20 & 82 & 740 & 33.91 & 24 & 24 & 13.36 & 4 & 23 & & 1.45 & 26 & 15.55 & & $c \mid$ & 2.02 & 25 & 898 & 73) & 100.50 \\
\hline & 19 & 128 & 40.65 & 96 & 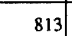 & 38.61 & 25 & 25 & 13.88 & & 29 & & 2.50 & 30 & 17.59 & & 16 & 2.02 & 28 & 995 & 79 & 115.24 \\
\hline 部 & 1990.5 & 162 & 50.94 & 151 & 1,226 & 62.16 & 31 & 31 & 15.93 & 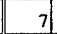 & 65 & 13 & 4.84 & 32 & 24.80 & & 25 & 2.14 & 390 & 1.484 & 101 & 160.81 \\
\hline & 1993.6 & 184 & 58.26 & 184 & & 86.39 & 7 & 29 & 16.25 & 10 & 94 & 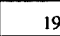 & 7.54 & 1 & 35.20 & 15 & 35 & 8.16 & 483 & 1,898 & 144 & 211.80 \\
\hline & 1995.5 & 195 & 59.60 & 200 & 1,7 & 93.94 & 30 & 30 & 16.58 & 11 & 104 & 21 & 8.70 & $\begin{array}{l}49 \\
\end{array}$ & 37.37 & 32 & 59 & 11.41 & 517 & 2,032 & 159 & 227.59 \\
\hline & 1979.7 & 98 & 29.36 & 69 & 7 & 38.66 & 21 & 21 & 59 & & 42 & & 3.69 & 18 & 9.28 & 7 & 35 & 5.22 & 218 & 828 & 87 & 94.79 \\
\hline & 1981.5 & 115 & 35.13 & 180 & & 79.23 & 35 & 36 & 13.14 & 10 & 138 & 13 & 5.38 & 32 & 14.96 & 11 & 52 & 7.83 & 383 & 2,09 & 133 & 55.66 \\
\hline 都 & 1982.5 & 142 & 38.68 & 190 & & 82.05 & 35 & 35 & 13.48 & 15 & 124 & 35 & 6.51 & 3 & 13.25 & 10 & 51 & 6.93 & 423 & 2,443 & 152 & 60.90 \\
\hline & 1984.5 & 174 & 45.41 & 290 & & 7.46 & 43] & 44 & 17.67 & 16 & 149 & 36 & 6.98 & 39 & 17.59 & 11 & 53 & 7.09 & 573 & 3,86 & 172 & 222.20 \\
\hline 心 & 1985.5 & 183 & 47.56 & 349] & 4,350 & 161.86 & 45 & 46 & 18.60 & 23 & 204 & 45 & 10.08 & 49 & 26.28 & 13 & 58 & 7.67 & 662 & 4,782 & 198 & 72.05 \\
\hline & 1987.4 & 207 & 51.65 & $401]$ & & 186.37 & 47 & 48 & 19.99 & 23 & 204 & 45 & 10.08 & 53 & 27.92 & 3 & 58 & 7.67 & 744 & .585 & 204 & 03.67 \\
\hline 北 & 1990.5 & 208 & 52.29 & 480 ] & $6,383]$ & 0.48 & 50 & 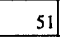 & 20.99 & 30 & 314 & כ5 & 12.59 & 52 & \begin{tabular}{|l|l} 
& \\
27.81 &
\end{tabular} & 16 & 66 & 9.67 & 836 & 93. & 224 & 353.83 \\
\hline & 1993.6 & 219 & 58.08 & 59| & 32 & 288.21 & 54 & 54 & 23.17 & 41 & 52 & 75 & 20.35 & 73 & 51.50 & 17 & 74 & 9.67 & 963 & 3,325 & 210 & 450.98 \\
\hline & 995.5 & 210 & .87 & 16 & 30| & 0.78 & 56 & 56 & 1.90 & 49 & 693] & 86 & 26.07 & 72 & 50.77 & 18 & 77 & 10.30 & 1,021 & 9.285 & 291 & 13.70 \\
\hline & 979.7 & 64 & .22 & 65 & $880 \mid$ & 33.31 & 23 & 23 & 10.68 & & & 12 & 5.18 & 58 & 7.16 & 14 & 71 & 9.44 & $23 !$ & 1,0 & 16 & 25.00 \\
\hline & 1981.5 & 114 & 41.90 & 99 & 1,308 & 51.97 & 31 & 33 & 12.62 & & 72 & 25 & 7.47 & 84 & 60.55 & 33 & 176 & 20.09 & 37 & 1,52 & 318 & 194.58 \\
\hline 都 & 1982.5 & 131 & 43.71 & 106 & 239 & 56.83 & 35 & 39 & 14.55 & 10 & 117 & 38 & 10.1 & 80. & 68.52 & 34 & 221 & 27.15 & 39 & 1,5 & 37 & 220.90 \\
\hline & 1984.5 & 144 & 49.67 & 143 & 377 & 75.95 & 41 & 46 & 18.60 & 19 & 259 & 58 & 13.51 & 98. & 80.80 & 42. & 257 & 30.72 & 48 & 2,3 & 455 & 269.2 \\
\hline & 1985.5 & 153 & .14 & 80 & 376 & 96.48 & 45 & 50 & 19.78 & 33 & 461 & 86 & 22.35 & 110 & 87.30 & 53 & 322 & 39.41 & 57 & 3,0 & 568. & 317.46 \\
\hline & 1987.4 & $166 \mid$ & .87 & 193 & 2,661 & 6.82 & 46 & 51 & 19.89 & 34 & 499 & 90 & 24.17 & 122 & 98.42 & 57) & 343 & 42.24 & 61 & 3.3 & 606 & 48.4 \\
\hline 心 & 1990.5 & 168 & .55 & 66 & 2,995 & 0.56 & 47 & 55 & 20.42 & 43 & 577 & 113 & 29.76 & 153 & 27.86 & 70 & 416 & 51.21 & 707 & 3,7 & 737 & 07.3 \\
\hline & 1993.6 & 170 & 57.52 & 234 & 3,223 & 31.98 & 44 & 44 & 18.96 & 43 & 654 & 114 & 32.26 & 170 & 0.40 & 79 & 452 & 54.91 & 740 & 4,0 & 780 & 36.02 \\
\hline & 1995.5 & 176 & .77 & 244 & 3,375 & 36.37 & 54 & 64 & 24.93 & 49 & 757 & 21 & 38.49 & 167. & 15.80 & 85 & 469 & 59.78 & 775 & 4,362 & 821 & 465.14 \\
\hline & 1979.7 & 132 & 92.96 & 6 & 55 & 3.63 & 18 & 18 & 12.18 & & 13 & & 1.25 & 29 & 17.07 & & & 0.25 & 18 & 218 & 60 & 127.33 \\
\hline & 1981.5 & 270 & .15 & 41 & 446 & 27.03 & 37 & 40 & 21.03 & & 27 & 12 & 4.29 & 52 & $\begin{array}{r}35.62 \\
\end{array}$ & & 50 & 4.62 & 412 & 780 & 181 & 225.75 \\
\hline 都 & 1982.5 & 368 & 159.83 & 30 & 607 & 30.79 & 40 & 46 & 20. & & 27 & 10 & 3.00 & 57 & 44.95 & 13 & 71 & 7.86 & 536 & 1,042 & 215 & 266.60 \\
\hline & 1984.5 & 544 & 2.53 & 86 & 1,005 & 46.07 & 58 & 66 & 26.95 & & 77 & 25 & 7.67 & 69 & $\begin{array}{r}54.18 \\
\end{array}$ & 18 & 85 & 10.17 & 784[ & 1,684 & 291 & 357.57 \\
\hline 心 & 1985.5 & 603 & .00 & 122 & 388 & 69.89 & 62 & 70 & 28.18 & 13 & 89 & 38 & 1.31 & 83 & 63.85 & 22. & 99 & 12.73 & 905 & 2,142 & 360 & 116.95 \\
\hline & 1987.4 & 754 & .53 & 61 & 787 & 89.96 & 68 & 76 & 31.97 & 17 & 130 & 51 & 13.84 & 96 & 72.24 & 27. & 115 & 15.23 & 1,123 & 2,739 & $428 \mid$ & 193.77 \\
\hline 南 & 1990.5 & 936 & 6.63 & 97 & 2,853 & 168.84 & 85 & 95 & 40.43 & 33 & 269 & 98 & 23.70 & 127. & 85.54 & 34 & 131 & 18.54 & 1,512 & 4,143 & 620 & 63.67 \\
\hline & 1993.6 & 1,074 & 991 & 83 & .565 & 2.53 & 91 & 91 . & 42.39 & 44 & 413 & 17 & 36.87 & 151 & 5.88 & 44 & 169 & 24.51 & \begin{tabular}{|l|l|} 
\\
\end{tabular} & 143] & 761 & 8.09 \\
\hline & 1995.5 & 1,137 & 375.91 & 449 & 4,209 & 271.68 & 103 & 105 & 48.02 & 49 & 511 & 129 & 40.22 & 151 & 111.30 & 48 & 180 & 26.15 & $\mid 1,937$ & 5,960 & 837[ & 873.29 \\
\hline & 1979.7 & 89 & 33.92 & 3 & 51 & 1.69 & 12 & 12 & 4.55 & 1 & 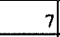 & 2 & 0.96 & 18 & 11.34 & & & 0.36 & 124 & 159 & 36 & 2.82 \\
\hline & 1981.5 & 219 & 73.38 & 7 & 82 & 3.69 & 20 & 20 & 6.69 & 3 & 34 & 14 & 2.23 & 27) & 16.12 & 4 & 16 & 2.55 & 280 & 355 & 77 - & 4.65 \\
\hline 南 & 1982.5 & 269 & 85.52 & 8 & 88 & 4.16 & 32 & 33 & 13.91 & 3 & 34 & 13 & 2.43 & 24 & 14.51 & 4 & 16 & 2.92 & 340 & 422 & 86 & 3.44 \\
\hline & 1984. & 353 & 112.64 & 15. & 212 & 10.67 & 33 & 34 & 14.20 & 3 & 34 & 13 & 2.77 & 32 & 19.07 & 3 & 19 & 3.26 & 441 & 632 & 88] & 2.61 \\
\hline & 1985.5 & 420 & 3.69 & 36 & 431 & 23.52 & 38 & 39 & 16.92 & 5 & 58 & 16 & 3.77 & 54 & 53.77 & 9 & 33 & 5.36 & 562 & 447] & 142 & 7.03 \\
\hline & 1987.4 & 482 & 152.77 & 71 & 621 & 35.09 & 41 & 42 & 17.75 & 5 & 58 & 16 & 3.77 & 59 & 55.50 & 9 & 33 & 5.36 & 667 & 1,202 & so & 0.23 \\
\hline 部 & 1990.5 & 67 & 203.63 & 159 & 1,218 & 77.46 & 54 & 56 & 22.52 & 10 & 135 & 22 & 7.01 & 71 & 49.57 & 12 & 46 & 6.35 & 982 & 2,083 & 195 & 6.54 \\
\hline & 1993. & 828 & 238.20 & 276 & 2,170 & 2.61 & 61 & 61 & 25.29 & 17 & 176 & 35 & 10.75 & 115 & 81.83 & 16 & 55 & 8.49 & 1,313 & 3.235 & 266 & .17 \\
\hline & 1995.5 & 919 & 264.79 & 324 & 2,542 & 178.65 & \begin{tabular}{|l|}
64 \\
\end{tabular} & 64 & $\begin{array}{l}27.39 \\
{[}\end{array}$ & 20 & 205 & 45 & $15.53]$ & 125 & 86.86 & 19 & 68 & 10.11 & 1,471 & 3,730 & 302 & 583.32 \\
\hline
\end{tabular}

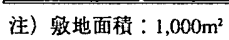


昇率が高く類似している。東京へのアクセスは多様化・利便化して いるが, 東京の通勤圏となるほどの近接性は有せず，一方地域の中 心的都市として土浦市との格差は, 時間の経過に従って安定的に縮 小しているが，いまた研究学園都市が突出して，周辺地域におおき な影響を及ぼすほどではないものと考えられる。

研究所数は, 1986年以降，急激な上昇曲線を描くパターンとなっ ている。これは万博期までは国立研究機関の移転による安定した増 加であったが, 万博以降研究学園都市のイメージが定着化し, 多数 の民間研究所が立地した結果であろう。

この中で特徴的な変化パターンをとるのが，都心地区延床面積で ある。1982年までは微増であったが，万博期には急増化し注8), 1987 年以降ゆるやかな増加に転じるパターンとなっている。学園都市の 都心地区は，公共施設と共に民間によるサービス施設などが立地す る。概成及び万博といった研究学園都市の都市的基盤の成立とイメ ージの定着化により，都市としてのポテンシャルか顕在化するよう になったことを反映している。

\section{4. 民有地の市街化の促進要因}

次に，図 3 に示した都市形成を記述する各指標と民有地の市街化 面積率との関係を見るため, 過去11時点のデータを用い市街化面積 率を目的变数として，重回帰分析を行った。

まず，公的市街地市街化面積率を除く7つの各指標值注9)をその まま用いて変数とし，変数増減法 (STEPWISE) により重回帰式を

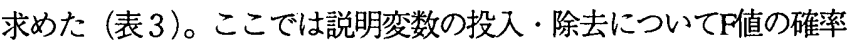
(0.05) を基準值としている。この結果，土浦市に対する小売販売額 比と都心地区の延べ床面積の2指標が市街化面積率に対する寄与が 高いことが分かる。

しかし，これらの指標はどれも時間とともに増加，または減少し ており，各指標間の相関も著しく高い。一般的に新都市の都市化， 市街化を表現する指標は，時間の経過とともに上昇，下降するする 傾向が強く, 市街化面積率の増加に対する寄与をこの結果からその まま判断することは危険である注10)。そこで，小売販売額比（対土 浦)，都心地区総延床面積（ともに説明変数）と市街化面積率（目 的変数)について各時点の変動率 (年率) を算出し (表 4), 市街 化面積率の増加そのものに対する意味を考察することとした。3変 数を用いて同様に重回帰分析を行った結果が表 5 である。

先の分析と比較して，2指標の順位は逆転しているが，充分な説 明力のある重回帰式か得られた（VIF=1.012）。この結果，2つの変数 の意味を次のように解釈することができる。

まず，「都心地区延床面積」は新都市の中心部の充実の度合いを 示し，市街化面積率に極めて大きく関係している。都心地区には， 各種の行政機関, 文化施設, 公的住宅, 商業・業務施設, 立体駐車 場.などが建設されてきた。このことから，このような公有地を中 心とした都心地区の発展, 開発の計画, 実施が, 直接新都市の民有 地の市街化と大きく関係していること，つまり都心地区の充実か新 都市の市街化を大きく促進することにつながっていると解釈するこ とができる。

逆に新都市外部との関係である「小売販売額比（対土浦)」は， 前者に比較して弱い関係ではあるが，新都市の発展による結果と解 釈できる。新都市の発展の結果, 两都市の相対的な関係の変化とし
表 3. 変数増减法による重回帰分析

\begin{tabular}{|c|c|c|c|}
\hline 重相関係数 & 0.9982 & \multirow{2}{*}{\multicolumn{2}{|c|}{$\begin{array}{l}\text { 自的変数：市街化面積率 } \\
\text { 変数選択：STEPISE }\end{array}$}} \\
\hline 決定係数 & 0.9965 & & \\
\hline 自由度修正済決定係数 & 0.9961 & 判定（分散分析） & \\
\hline 標準誤差 & 1.0498 & ** (1\%有意) & \\
\hline 指標 & ベータ係数 & 偏相関係数 順位 & $\mathrm{t}$ 検定 判定 \\
\hline 小売販売額比 (対土浦) & 0.8727 & 0.9895 & $0.00 * *$ \\
\hline 都心地区延床面樻 & 0.1326 & 0.7211 & 0.02 \\
\hline 専業農家率 & 0.0186 & 0.3360 & 0.38 \\
\hline 集合住戸率 & -0.0166 & -0.3086 & 0.42 \\
\hline 研究所数 & 0.0981 & 0.5561 & 0.12 \\
\hline 昼夜間人口比 & -0.4797 & -0.3557 & 0.35 \\
\hline 東京へのアクセス & -0.0149 & -0.0889 & 0.82 \\
\hline
\end{tabular}

\section{表 4. 変動率の推移}

\begin{tabular}{cccc}
\hline $\begin{array}{c}\text { 期間 } \\
\text { (年) }\end{array}$ & $\begin{array}{c}\text { 市街化速度 } \\
\text { (年率) }\end{array}$ & $\begin{array}{c}\text { 都心地区 } \\
\text { 延床面積 } \\
\text { 変動率 }\end{array}$ & $\begin{array}{c}\text { 小売販売額比 } \\
\text { (対土浦) } \\
\text { 変動率 }\end{array}$ \\
\hline $73-77$ & 1.700 & 0.290 & 0.004 \\
$77-79$ & 2.400 & 0.455 & 0.038 \\
$79-81$ & 3.109 & 0.145 & 0.039 \\
$81-82$ & 1.900 & 0.000 & 0.039 \\
$82-84$ & 2.450 & 2.540 & 0.032 \\
$84-85$ & 5.200 & 10.190 & 0.033 \\
$85-87$ & 1.148 & 0.000 & 0.018 \\
$87-90$ & 2.822 & 2.300 & 0.035 \\
$90-93$ & 3.146 & 0.087 & 0.037 \\
$93-95$ & 2.557 & 1.585 & 0.034 \\
\hline
\end{tabular}

表 5. 変動率を用いた重回帰分析

\begin{tabular}{|c|c|c|c|}
\hline 重相関係数 & 0.9013 & 目的变数：市街化 & 面積増加率 \\
\hline 決定係数 & 0.8124 & & \\
\hline 自由度修正済沫 & 0.7588 & 判定（分散分析） & \\
\hline 標準誤差 & 0.5385 & ** (1\%有意) & \\
\hline 指標 (増加率) & ベータ係数 & 偏相関係数 順位 & t検定 判定 \\
\hline 都心地区延床面積 & 0.7931 & 0.8765 & $0.00 * *$ \\
\hline 小売販売額比（対土浦） & 0.3511 & 0.6275 & $0.07+$ \\
\hline
\end{tabular}
$\mathrm{t}$ 検定判定: ${ }^{* *} 1 \%$ 有意, $+10 \%$ 有意

て, 発展の状況を示している点は興味深い。旧来のこの地域の中心 都市であった土浦市の存在は，この新都市立地の一つの要因であっ た。したがって職住近接の独立した都市として計画された新都市が， 初期には土浦市に様々な面で依存する部分が大きかったと考えられ るが，旧都市とは独立した都心形成とこれにともなう民有地の市街 化を経て，目指す姿に近ついているといえよう。小売販売額が土浦 市郊外部の大型店舗等も含んでいることを考慮すると，両都市は茨 城県南地域の 2 つの中的核として順調に発展しているといえよ 门。

\section{5. まとめ}

本研究の結果をまとめるとは以下のとおりである。 (1)筑波研究学園都市の民有地の市街化は, 市街化面積率で見る限 り，全体的には非常に安定的に推移してきたが，その詳細を見ると， 1)万博以前の安定的市街化時期，2)万博を中心とした急激な市街化 と停滞期，3)1990年以降の研究学園都市の都市的ポテンシャルの顕 在化による上昇期，の3つの時期に分かれる。

(2)民有地の市街化は，集合型住宅の建設にリードされる特徴があ るが，これは上記の1)，2)の時期では主として大学活動の影響によ るものであり，地域的に偏在するのに対し，3)では，都市内および 
周辺に立地する研究所などの影響を受けており，集合住宅化が都市 全体に及ぶようになっている。

(3)この22年間を通じて，民有地の市街化の要因として，都心地区 の成長・充実があげられる。万博の開催それ自体は，研究学園都市 特有の事象であるが, 大型ショッピングセンターや中央公園の建設 など都心地区の成熟に大きく寄与したことから万博直前も含めて，以 降の市街化を促進することにつながっていると考えられる。すなわ ち民有地の市街化にあたって, 都心の充実化を図る方策が, 新都市 計画の重要な課題と言えよう。

\section{謝辞}

本研究の調査は，20年にわたり若林時郎，志田隆秀，馬越正哲， 坂本至, 桑原盾, 村上真祥, 河津玲の各氏をはじめ筑波大学の多く の教官, 技官, 大学院生と共同で行ってきたものである。また調查 実施にあたっては住宅・都市整備公団つくば開発局の協力を得た。 合わせて感謝の意を表します。

\section{注}

1)ここで言う民有地とは，住宅・都市整㣁公団施行の土地区画整理事業におお いて，民間地権者の所属となった民有換地を指す。

2)研究学園都市土地区画整理の詳細については文14を参照されたい。 3)本研究における「ビルトアップ」とは, 個々の宅地に建築物か建てられる 現象であり，「市街化」とは，一定の地域においてビルトアップが進行し 市街地を形成していく状況を指している。

4)各時期の報告については，文1一文10を参照されたい。

5)1985年調查までは，建筑物の減少を提えることは調査において非常に労力 を要し，また量的にも無視しうるものであったため実施しなかった。し かし，消失と建替えがかなり一般化してきていることから，1987年調査か らは，1985年調査のストック量を基硶に，新規建設量及び消失量を調べた。 ただし，本研究では，消失量を差し引いた現存量（ストック）に基づい て考察する。

6文15参照。

7)文 1 文10参照。

8)万博期に建設された施設として, クレオ(大型ショッピングセンター), つ くばセンタービル(ホテル，音楽ホールなどからなる複合施設), ユーティ リティーセンター(地域冷暖房システム), 中央公園が挙げられる。

9)冝夜間人口比，小売販売額比(対土浦)，専業農家率は国势調查，商業統計， 宸朴業センサスによる隔年統計データであるため，必ずしも市街化実態 調查年と時期が一致しない。しかし各指標とも一定の推移を示すことか ら (図 3), 調查年と一致しない場合は前後のデータから 1 年あたりの增 隇値を算出し，調査年值として割り付けた。

10)同様の理由から，重回㷌式における多重共線性の問題も考えられる（分 散インフレ保数VIF=9542)。

\section{参考文献}

1)土肥博至 ·若林時郎他 : 筑波研究学園都市の形成一中間期 (昭和52年) の 状況一（その2), 昭和51年度日本建築学会関東支部研究報告集, pp 417 416, 1978

2)土肥博至・若林時郎他 : 筑波研究学園都市に拈りる民有地の市街化に関す 万研究, 昭和 55 年度日本建築学会関東支部研究報告集, pp 401 420, 日本 建築学会, 1981

3)若林時郎 ·土肥博至 - 志田隆秀 : 筑波研究学園都市における民有地の市街 化に関する研究 2 (1981年までの状況), 昭和57年度日本建築学会関東支部 研究報告焦, pp 317 324, 日本建築学会, 1983

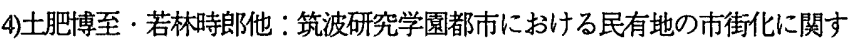

万研究 3 (1982年までの状況), 昭和58年度日本建築学会関東支部研究報告 集, p p309 324, 日本建築学会, 1984

5)若林時郎・土肥博至・馬越正哲 : 筑波研究学園都市における民有地の市街 化认関する研究4(1984年までの状況), 昭和60年度日本建築学会関東支部研 究報告集, pp $389 \sim 396$, 日本建築学会, 1986

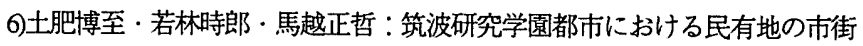
化に関する研究 5 (1985年までの状況)，昭和 55 年度日本建築学会関東支部 研究報告集，pp325 336，日本建築学会，1987

7)土肥博至 · 若林時郎 - 坂本至 : 筑波研究学園都市に拉ける民有地の市街化 に関する研究 6 (1987年までの状況), 昭和63年度日本建築学会関東支部研 究報告集, pp169 180, 日本建筑学会, 1989

8)若林时郎・土肥博至 - 坂本淳二 : 筑波研究学園都市に扩る民有地の市街 化に関する研究 7 (1990年までの状況)，1990年度日本建筑学会関東支部研 究報告集, pp209 200, 日本建管学会, 1991

9)土肥博至 · 村上真样・河津玲 : 筑波研究学園都市に扑る民有地の市街化 に関する研究8(1993年までの状況)，1993年度日本建筑学会関東支部研究報 告集, pp325 336, 日本建築学会, 1994

10)土肥博至他 : 筑波研究学園都市に抽尼有地の市街化に関寸る 研究 9 (1995年までの状況), 19955 年度日本建築学会関東支部研究報告集, p273 ～284, 日本建築学会, 1996

11)前田尚美：区画整理地区における住宅のビルトアップによる市街地形成 の問題（その 1 ), 日本都市計画学会学術論文報告集第 15 号, pp43 48, 日本都市計画学会, 1980

12)前田尚美 : 区画整理地区における住宅のビルトアップによる市街地形成 の問題 (その 2), 日本都市計画学会学術論文報告集第16号, pp163 168, 日本都市計画学会, 1981

13)石田頼房・波多野憲男：郊外土地区画整理事業における「おくれ」およ び「ずれ」について, 日本建築学会計画系論文報告集第311号, 1982 14)侏都市計画設計研究所：筑波研究学園都市民有換地の罢境整備基準作成 のための調查, 1977.9

15)若林時郎・土肥博至他 : 区画整理民有地の市街化過程に関する基碳的考 察, 日本都市計画学会学術論文報告集第17号, pp229 234, 日本都市計画 学会, 1982

16)中央地学 : 筑波研究学園都市土地法典, 中央地学, 茨城, $1981.6,1987.12$

（1997年 3 月 10 日原稿受理，1997年 9 月19日採用決定 